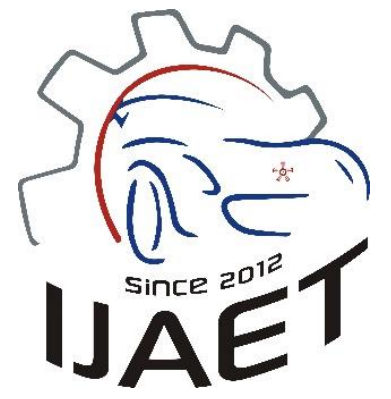

e-ISSN: 2146 - 9067

International Journal of Automotive

Engineering and Technologies

journal homepage:

https://dergipark.org.tr/en/pub/ijaet

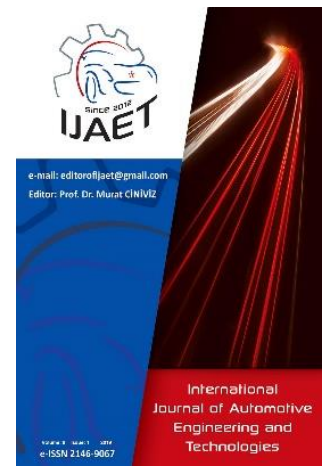

Original Research Article

\title{
Investigation of combustion and emission in a DI diesel engine fueled with hydrogen-biodiesel blends
}

\author{
İlker Temizer ${ }^{1}$, Ömer Cihan ${ }^{2 *}$ \\ ${ }^{1}$ Department of automotive engineering, Sivas Cumhuriyet University, Sivas, Turkey \\ ${ }^{2 *}$ Department of mechanical engineering, Hakkari University, Hakkari, Turkey
}

\section{ARTICLE INFO}

* Corresponding author omercihan@hakkari.edu.tr

Received: Sep 24, 2019

Accepted: Nov 03, 2019

Published by Editorial Board Members of IJAET

(C) This article is distributed by Turk Journal Park System under the CC 4.0 terms and conditions.

\begin{abstract}
The aim of this study was to determine the availability of canola oil methyl ester as an alternative fuel in diesel engines and by adding canola oil methyl ester and hydrogen to diesel fuel. This study was carried out experimentally and numerically. The engine was studied at $2000 \mathrm{rpm}$ speed and full load. The analyzes carried out in the AVL-FIRE ESE Diesel part.

In-cylinder combustion and emission analyzes were examined experimentally by adding $10 \%$ (B10) and $20 \%$ (B20) of the canola oil methyl ester to the diesel (D100) fuel. Also, hydrogen fuel by the amount of $3 \%$ and $6 \%$ of the mass were added to diesel and biodiesel mixture fuels to eliminate some disadvantages of biodiesel fuels. The obtained findings in experimental and numerical studies were similar to each other. The similarity of these results was also validated by numerical studies using hydrogen.

The boundary conditions obtained in experimental studies were determined, and the effect of hydrogen fuel on temperature, in-cylinder pressure, spray distribution and $\mathrm{CO}$ formation were examined numerically. In the experimental studies conducted with D100, B10 and B20 fuels, the maximum pressures in-cylinder were measured as 87 bar, 88 bar and 89.09 bar respectively. In numerical results, these values were recorded as $90.02,90$ and 93.8 bar respectively. Addition of $3 \%$ and $6 \%$ hydrogen to these three different fuel mixtures increased in-cylinder pressures and temperatures. Also, in-cylinder droplet diameters with the addition of hydrogen decreased in all test fuels. This situation led to a reduction in $\mathrm{CO}$ emissions.

Keywords: Diesel Engine; Hydrogen; Canola oil methyl ester: CO emission; AVL Fire.
\end{abstract}

\section{Introduction}

The oil sector has an important place in the world. Oil and petroleum products; It meets energy needs in many areas such as transportation, industrial manufacturing and small scale consumption. Today, because of the increasing number of vehicles and global climate changes, the consumption of fossil fuels is one of the most controversial issues. Energy is supplied from petroleum products worldwide, especially for internal combustion engines used for transportation and energy production.

Diesel engines in the class of internal combustion engines; is advantageous in terms of high efficiency, power, better fuel economy and emissions. Diesel engines are used in many 
areas such as truck, tractor, earth mover and passenger vehicles, all marine vehicles, locomotives, stationary power machines and generators. For this reason, it is very important to improve the combustion efficiency of diesel engines and to reduce emissions.

Various studies have been carried out on the efficient use of fuel in engines and the reduction of pollutant emissions in exhaust gases. Researches on the structural properties of the engines and the engine fuels are concentrated in these studies.

Alternative fuels have highlighted issues such as the increase of combustion efficiency, energy shortage, measures taken to protect the environment due to emission values and lower fuel consumption [1]. In diesel engines have been the subject of research many alternative fuels such as Bio-diesel, Biogas, Hydrogen, compressed natural gas (CNG), Hydrogen enriched natural gas (HCNG), Ethanol and Liquefied Petroleum Gas (LPG).

Hydrogen is an alternative fuel that can be used as automobile fuel. Hydrogen; is an alternative to hydrocarbon based fuels producing hydrocarbon (HC) and carbon monoxide (CO) [2]. However, Specific oxides of nitrogen $\left(\mathrm{NO}_{\mathrm{x}}\right)$ emissions increase due to increased combustion chamber temperature [3]. Hydrogen has some properties such as high flame speed and high thermal value [4]. Hydrogen is a renewable, highly efficient and clean fuel that has a great importance for the future of diesel engines [5]. The spontaneous ignition temperature of the hydrogen / air mixture is higher than for other fuels. Hydrogen is a clean fuel without carbon emissions. The combustion of hydrogen produces only water and some nitrogen oxides. It helps to reduce carbon dioxide $\left(\mathrm{CO}_{2}\right)$ emissions when used with fossil fuels. Hydrogen with these emission properties is the ideal fuel to meet the more stringent environmental controls associated with greenhouse gases and emissions [6]. Hydrogen has the ability to ignite in a large area long-term renewable and less polluting, non-toxic and odorless [7]. It is not possible to use hydrogen widely in vehicles in the near future due to the lack of hydrogen as a fuel substructure and lack of fuel supply stations [8]. In other respects, early ignition and early combustion occurs due to low ignition energy in the case of hydrogen- fueled engines. Also, water vapor in the hydrogen-air mixture causes a decrease in power as it reduces the combustion temperature. Furthermore, due to the low combustion rates in very poor mixtures, the contact of the new mixture with the combustion gases as a result of the increase in combustion time, hot particles from the engine oil can initiate the combustion before the desired. Therefore, it can be used with fuel types such as diesel and bio-diesel. Several studies have been conducted on the impact of the engine on performance and emissions.

Four-cylinder diesel engine is operated at full load and different speeds. $2.5 \%, 5 \%$ and $7.5 \%$ hydrogen are added inside diesel fuel. The torque, power, thermal efficiency, exhaust gas temperature and $\mathrm{NO}_{\mathrm{x}}$ are increased with the increase of hydrogen fuel in the engine. $\mathrm{HC}, \mathrm{CO}$ and $\mathrm{O}_{2}$ emissions are decreased [9].

Another study is a review study on the use of hydrogen-CNG mixture (HCNG) in internal combustion engines. Hydrogen fuel has decreased $\mathrm{HC}$ and $\mathrm{CO}_{2}$ emissions due to carbon deficiency compared to $\mathrm{CNG}$ fuel, while $\mathrm{NO}_{\mathrm{x}}$ emissions have increased due to chamber temperature rise. Also, the speed of laminar flame has increased with hydrogen [10]. The increase in laminar flame velocity with the addition of different amounts of hydrogen into natural gas is more clearly indicated by an experimental setup. The experimental setup consists of a spherical combustion chamber coupled to a classical shadowgraph system [11]. In addition, the speed of flame propagation increases as hydrogen fuel is added into the CNG [12]. As a result of the reaction of CNG fuel with hydrogen fuel, the stability of combustion has increased [13].

HCNG fuel can be used with fossil fuels. Thus, the efficiency and emission values reduces. In any case, if the advance is well adjusted, the engine torque increases [14]. The effect of the compression ratio is emphasized on torque, brake specific fuel consumption and emission parameters in a single cylinder diesel engine tested at different HCNG ratios [15]. Generally, when hydrogen is added into $\mathrm{CNG}$ fuel in the diesel engine, it is observed to reduce $\mathrm{HC}, \mathrm{CO}_{2}$ and $\mathrm{CO}$ emissions due to the absence of carbon in the hydrogen [16]. Also, NOx emissions increases due to the increase in combustion chamber temperature as well as combustion 
chamber pressure. In addition, hydrogen fuel has increased flame speed and thermal efficiency and reduced combustion duration. Maximum cylinder pressure and maximum heat release increases. Bsfc (Brake-specific fuel consumption) parameter is also reduced have been determined in different studies [1, 16-20]. One of the alternative fuels whose research extends to this day is the fuel (biodiesel), which is obtained from vegetable or animal oil. Biodiesel fuel is a fuel that has a lower $\mathrm{CO}_{2}$ emission and similar combustion characteristics as diesel fuel.

Many biodiesel fuels have been used to improve performance and emissions in diesel engines. Kumar and his friend, maduca longifolia oil (MO), ethanol, hydrogen and water injection fuels are operated in different ratios of singlecylinder diesel engine at $1500 \mathrm{rpm}, 3.7 \mathrm{~kW}$ power and full load. Ethanol is showed a higher ignition delay than hydrogen fuel. It has been seen that engine performance improves when ethanol, hydrogen and MO fuels are used together [21]. In another study, Pomegranate seed oil biodiesel (POB), hydrogen and diesel fuels are used in different ratios. Adding POB fuel to the diesel fuel in the engine has a positive effect on the engine power and bsfc parameters. Engine performance and emissions are improved with the addition of hydrogen fuel to these fuels [22]. Serin et. al, tea seed oil biodiesel, hydrogen and diesel fuels are investigated the effect on engine performance and emissions by using different ratios in a single cylinder diesel engine. Biodiesel is showed a positive effect on engine performance and bsfc parameters. While biodiesel reduced $\mathrm{CO}$ emissions, it has increased $\mathrm{CO}_{2}$ and $\mathrm{NO}_{\mathrm{x}}$ emissions [23]. In a single cylinder diesel engine, Waste oil biodiesel (WOB), hydrogen and diesel fuels are tested no-load at $1500 \mathrm{rpm}$. The addition of WOB fuel reduces thermal efficiency. WOB fuel increases fuel consumption and $\mathrm{CO}_{2}$ parameters. While thermal efficiency is increased by the addition of hydrogen fuel, fuel consumption, $\mathrm{CO}$ and $\mathrm{CO}_{2}$ emissions are decreased [24]. Tamanu methyl ester (TME), ethanol, diesel and hydrogen fuel are used as fuel in a diesel engine. Hydrogen fuel is provided high $\mathrm{NO}_{\mathrm{x}}$ emission and this $\mathrm{NO}_{\mathrm{x}}$ value is reduced by using TME + Ethanol fuel mixture [25]. When jatropha oil is used as a biodiesel in a diesel engine, it is seen that the thermal efficiency increased, while the soot, $\mathrm{HC}$ and $\mathrm{CO}$ emissions are decreased [26]. Another fuel used in diesel engines as biodiesel fuel is rapeseed oil (canola oil) fuel. There are experimental studies on rapeseed oil, hydrogen and diesel fuels in the literature. Rapeseed oil, hydrogen and diesel fuel are tested with different mixing ratios in diesel engine. The effects of combustion characteristics, performance and emissions are investigated with different rates of hydrogen fuel has added to B20 (20\% rapeseed oil and $80 \%$ diesel) fuel. Rapeseed oil fuel is reduced performance and efficiency while it is reduced other emissions without $\mathrm{NO}_{\mathrm{x}}$ emissions. Also, the ignition delay of this fuel is shorter. It doesn't have a significant effect on B20 fuel on ignition delay of hydrogen fuel $[27,28]$. In another study, rapeseed methyl ester (RME) and diesel fuel are used as pilot fuel, natural gas and hydrogen fuel are used as main fuel in a diesel engine. Experiments are performed at different engine speeds. It is observed that the delay of the ignition is shortened by pilot spraying of rapeseed methyl ester fuel [29]. In addition, a better trade-off between $\mathrm{HC}$ and $\mathrm{NO}_{\mathrm{x}}$ is attempted by pilot spraying of rapeseed methyl ester fuel [30]. Pilot fuel RME according to pilot fuel diesel, emission values are generally similar because of the physical and chemical properties [31]. It is determined that there is a better result in $\mathrm{NO}_{\mathrm{x}}$ emissions in the medium power range as pilot fuel RME and diesel fuel and as main fuel hydrogen-diesel fuel [32]. In another experimental study, as pilot fuel RME and diesel fuel and as main fuel natural gas are used. The lower thermal efficiency of the RME fuel compared to diesel fuel is obtained [33]. RME fuel according to diesel fuel, $\mathrm{CO}_{2}$, UHC and $\mathrm{NO}_{\mathrm{x}}$ emissions are lower and thermal efficiency is higher in different speed and load conditions [34].

Increased canola oil methyl ester in diesel fuel due to incomplete combustion, this situation increased emissions of $\mathrm{O}_{2}$ while reducing $\mathrm{CO}$ emissions in exhaust emissions. Also, exhaust gas temperature has decreased [35].

Many of the rapeseed-hydrogen fuel uses in the literature are related to the effects of engine performance and emissions. Also, in general studies, rapeseed oil is used by mixing with 
methyl ester. In the present study, the effects of different proportions of diesel, canola oil methyl ester and hydrogen fuels were investigated on combustion characteristics and emissions. Both experimental and modeling were performed with different fuel mixture ratios at $2000 \mathrm{rpm}$ engine speed and full load. All features of the engine were constant kept except for the fuel ratio for fully understand the effect of used fuels on the combustion and emissions. The difference of this study from literature, chamber pressure and temperature, heat release, state of the fuel-air mixture inside the chamber, spraying process, particle formation, evaporation and temperature distribution of the fuel were examined by using the ESE-DIESEL part of the AVL-FIRE software in the model. After that, the experiments were carried out on diesel fuel, B10 (10\% canola oil methyl ester $90 \%$ diesel) and B20 (10\% canola oil methyl ester $90 \%$ diesel) fuels, and this results were compared with the model. The results obtained from the models and experiments were found to be close to each other. Then, the effects of hydrogen on combustion and emissions were investigated by adding $3 \%$ and $6 \%$ hydrogen to the diesel, B10 and B20 fuels in the model.

\section{Material Method}

\subsection{Experimental study}

The air-cooled, single-cylinder Antor 3LD 510 direct injection diesel engine was used as the test engine. In-cylinder pressure measurement of the engine was used in the Febris combustion analysis program. Combustion chamber pressure was measured by the Optrand brand optical fiber pressure sensor. After connecting the encoder and the pressure sensor to the single cylinder diesel engine, the data obtained was transferred to the computer instantly by way of the Febris interface. The engine was operated at full load and maximum torque. The engine test setup was given in Figure 1. The technical specifications of the engine were given in Table 1. Also, experimental test uncertainty analysis results were showed in Table 2.

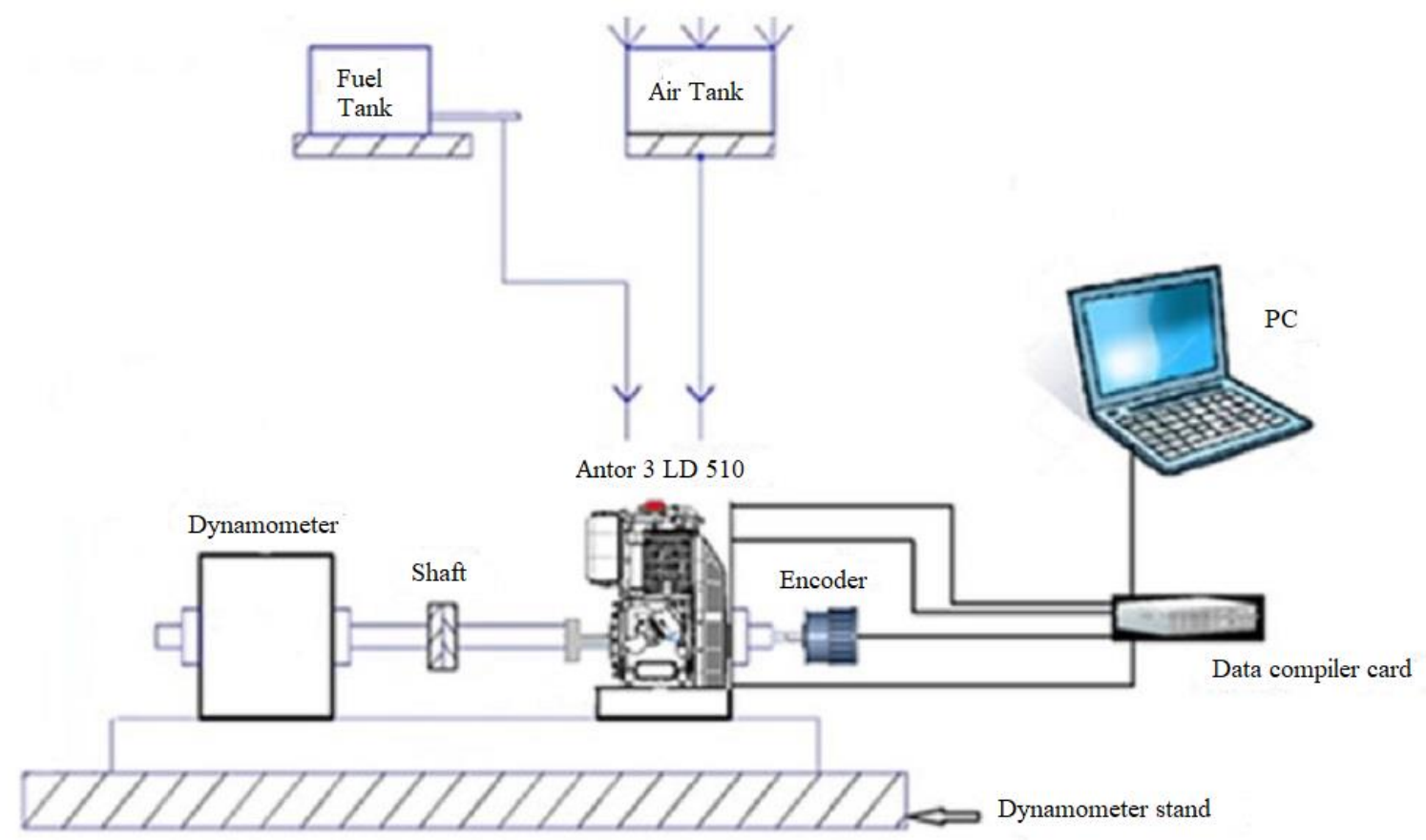

Figure 1. Schematic view of the experimental setup.

Table 1. Test engine specifications.

\begin{tabular}{ll}
\hline \multicolumn{1}{c}{ Specifications } & \multicolumn{1}{c}{ Descriptions } \\
\hline Engine Type & 4- stroke, direct injection diesel engine \\
Number of cylinders & 1 \\
Cylinder volume & $510 \mathrm{~cm}^{3}$ \\
Bore x Stroke & $85 \times 90(\mathrm{~mm} \mathrm{x} \mathrm{mm})$ \\
Compression ratio & $17.5: 1$ \\
Maximum power & $8.8 @ 3000(\mathrm{~kW})$ \\
Maximum torque & $32.8 @ 1800(\mathrm{Nm})$ \\
Injection angle & $126^{\circ}$ \\
Number of Nozzles & 4 \\
\hline
\end{tabular}


Table 2. Uncertainties of experimental measurement devices

\begin{tabular}{lll}
\hline Pressure Sensor & Encoder & Electric dynamometer \\
\hline Optrand fiber optic & Cubler & Baturalp Tayland brand brake \\
Measuring range 0 -200 bar & Measuring range 0-12000 rpm & Maximum torque of 80 Nm \\
$0,025 \mathrm{~V} /$ bar sensitivity & Encoder resolution 360x $1^{\circ} \mathrm{CA}$ & $\% \pm 0.02$ Uncertainty \\
$120 \mathrm{kHz}$ natural frequency & Converts angle value to digital TTL signal & Torque sensor \pm 10 VDC output \\
$\% \leq \pm 0,5$ accuracy & It can be supplied with 5V or $120 \mathrm{~mA}$ & Powered by 220 Volt voltage \\
Measurement in temperature & Measurement in temperature range -40 and & Measurement in temperature range \\
range -40 and $360^{\circ} \mathrm{C}$ & $85^{\circ} \mathrm{C}$ & -10 and $60^{\circ} \mathrm{C}$ \\
\hline
\end{tabular}

\subsection{Numerical study}

The analysis of fuels with different ratios was made by ESE-DIESEL part of the AVL-FIRE software. In this program were simulated parameters such as combustion temperature, viscosity, particle distribution, ignition delay, emission and engine performance values. All values of the single cylinder engine were taken in the conducted analysis. WAVE model was used as breakup model in the mode, k-zeta-f model was used as a turbulence model, MultiComponent as an evaporation model. Also ECFM-3Z model were used as a combustion model. Wall interaction model known as "Wall jet 10" was used for hydrogen, canola oil methyl ester and diesel fuels in the numerical study. The spray angle was defined as $126^{\circ}$ in this analysis [36-39]. This model simulates separated of small droplets from the fuel particle. In the model, the spray wall interaction model was used to calculate the effect of non-atomizable or non-vaporized fuel on the combustion chamber walls of the sprayed fuel. On the other hand, this model could be used for EGR and spray type combustion models. Hydrocarbon based many fuels could be defined in the ECFM-3Z model. The extended Zeldovich model was used for NO emissions. As initial conditions, the temperature and pressure values were taken respectively 293 $\mathrm{K}$ and $1 \mathrm{Bar}$. The cylinder walls and cylinder head values were fixed in the boundary conditions and also the piston was selected as the moving boundary condition. On the other side, C2-13 Weber number model was performed depending on physical and dynamic parameters of sprayed and dispersed fuel in Wave fragmentation model. To investigate the mesh independency, it was considered containing a different number of cells. Though the resulting combustion parameters were identical for all cases, the case which contained approximately 50,000 cells had closest result compared to experimental results. The geometry of the combustion chamber was given in Figure 2. The input and boundary conditions were given in Table 3.

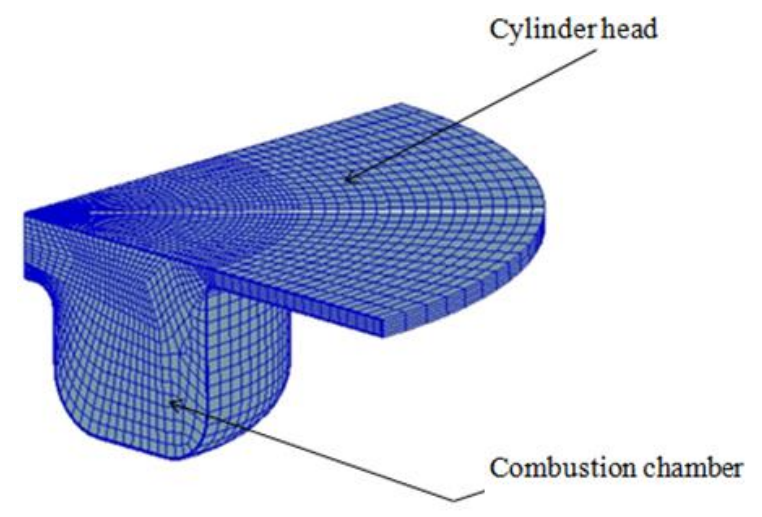

Figure 2. Combustion chamber geometry.

Table 3. Determined initial and boundary conditions.

\begin{tabular}{ll}
\hline \multicolumn{1}{c}{ Specifications } & \multicolumn{1}{c}{ Descriptions } \\
\hline Engine speed & $2000(\mathrm{rpm})$ \\
Air inlet temperature & $293.15(\mathrm{~K})$ \\
Air inlet pressure & $1(\mathrm{bar})$ \\
Fuel injection temperature & $330.15(\mathrm{~K})$ \\
Cylinder head temperature & $575.15(\mathrm{~K})$ \\
Cylinder wall temperature & $475.15(\mathrm{~K})$ \\
Spraying range & $-20-0(\mathrm{KA})$ \\
Fuel consumption & $1.9(\mathrm{lt} / \mathrm{h})$ \\
\hline
\end{tabular}

Test fuels consist of diesel, canola oil methyl ester and hydrogen fuels in the AVL-FIRE library. The engine torque was selected as 2000 rpm in the numerical study. Model had been created by keeping constant parameters such as engine volume, cylinder volume, compression ratio, injector angle and nozzle structures, exhaust and intake valve opening and closing advances. Fuel injection pressure is 200 bar both experimental and numerical. The effects of different fuel mixtures were investigated on combustion characteristics and emissions. Numerical studies were compared with experimental data in different fuel types. The properties of diesel-hydrogen and diesel-canola oil methyl ester fuels were given in Table 4 .

\section{RESULTS}

The analysis of the combustion in the engine 
should be interpreted as an indicator of some parameters in-cylinder. The crankshaft angle measured by the encoder connected to the crankshaft was measured in the engine.

Table 4. Comparison of diesel fuel and hydrogen characteristics [40,41].

\begin{tabular}{llll}
\hline Properties & Diesel & Hydrogen & Canola oil methyl ester \\
\hline Formula & $\mathrm{n}-\mathrm{C}_{13} \mathrm{H}_{28}$ & $\mathrm{H}_{2}$ & - \\
Auto ignition temperature $(\mathrm{K})$ & 530 & 858 & - \\
Minimum ignition energy $(\mathrm{MJ})$ & - & 0.02 & - \\
Flammability limits (volume \% in Air) & $0.7-5$ & $4-75$ & - \\
Stoichiometric air-fuel ratio on mass basis & 14.5 & 34.3 & - \\
Molecular weight (g/mole) & 100 & 2 & - \\
Limits of flammability & - & $0.1-7.1$ & - \\
Density at $160{ }^{\circ} \mathrm{C}$ and 1.01 bar $\left(\mathrm{kg} / \mathrm{m}^{3}\right)$ & $833-881$ & 0,0838 & 881 \\
Net heating value $(\mathrm{Lower})(\mathrm{MJ} / \mathrm{kg})$ & 42.5 & 119.93 & - \\
Flame velocity $(\mathrm{cm} / \mathrm{s})$ & 30 & $265-325$ & - \\
Quenching gap in NTP Air $(\mathrm{cm})$ & - & 0.064 & - \\
Diffusivity in Air $\left(\mathrm{cm}{ }^{2} / \mathrm{s}\right)$ & - & 0.63 & - \\
Octane number & 30 & 130 & - \\
Cetane number & $40-55$ & - & $45-59$ \\
Calculated cetane index distillation $(\%)$ & 57.8 & - & $47.2-55$ \\
Boiling point $(\mathrm{K})$ & $436-672$ & $20-27$ & - \\
Pour point $\left({ }^{\circ} \mathrm{C}\right)$ & -6 & - & -10.0 \\
Freezing point $\left({ }^{\circ} \mathrm{C}\right)$ & - & - & -12.9 \\
Ester content $(\%)$ & - & - & 99.6 \\
Flash point $\left({ }^{\circ} \mathrm{C}\right)$ & 58 & - & 135.7 \\
Viscosity at $15.5{ }^{\circ} \mathrm{C}$, centipoise $\left(\mathrm{mm}{ }^{2} / \mathrm{s}\right)$ & $2.6-4.1$ & - & 4.44 \\
Specific gravity & 0.83 & 0.091 & - \\
\hline & & & \\
\hline
\end{tabular}
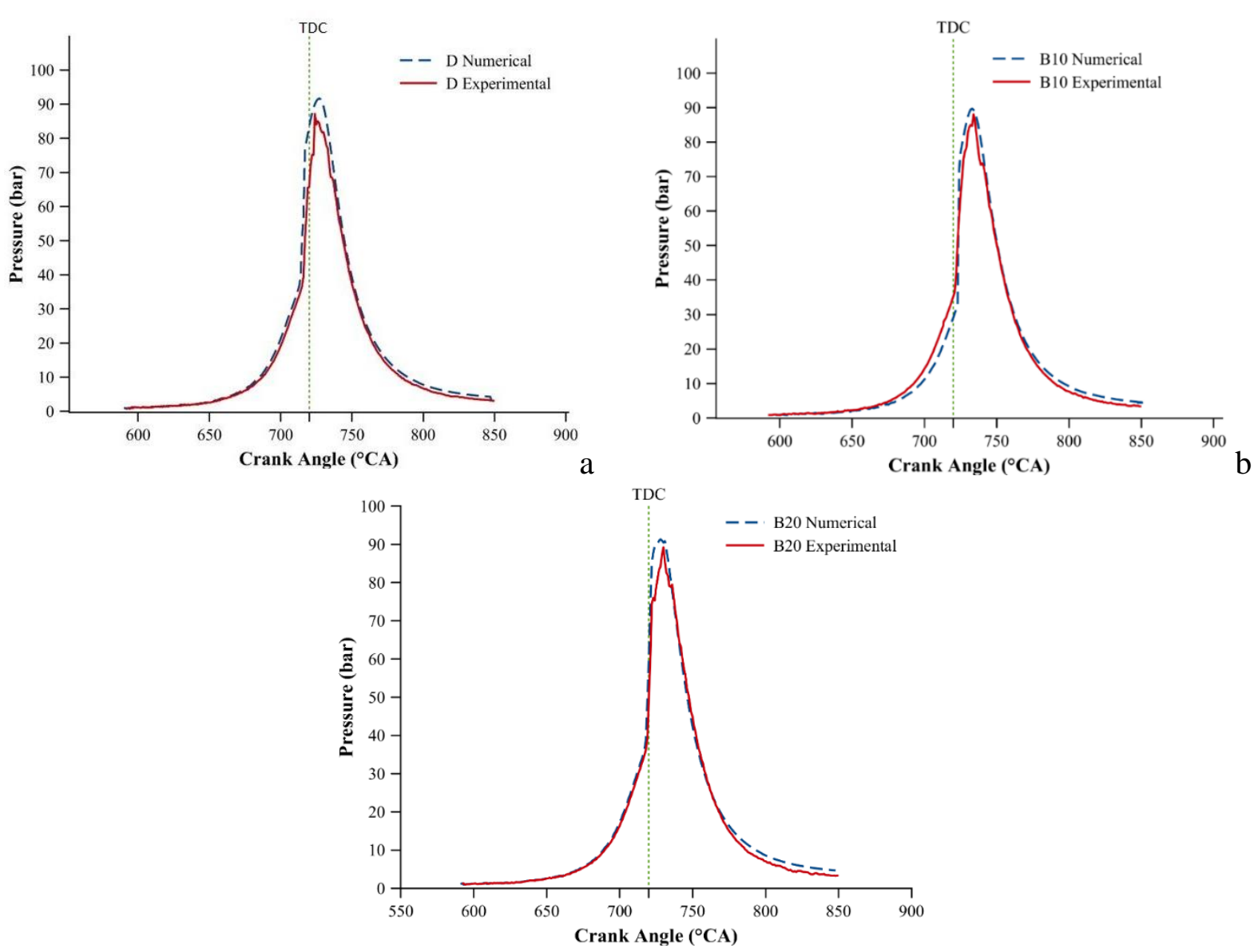

Figure 3. Experimental and numerical comparison of in-cylinder pressure changes of Diesel (a), B10 (b) and B20 (c) fuels. 
important parameter used in the combustion analysis of the engine. The engine experiments performed in this study were modeled numerically in the AVL-Fire program. Thus, numerical and experimental results were presented comparatively, and the validity of the numerical model was emphasized. In the experiments, diesel fuel, B10 (10\% canola oil methyl ester $90 \%$ diesel) and B20 (10\% canola oil methyl ester $90 \%$ diesel) fuels were performed at $2000 \mathrm{rpm}$ engine speed and full load. The in-cylinder pressure values of these fuels depending on the crank angle were compared both experimentally and numerically (Figure 3).

It is seen in all test fuels where the pressure values obtained from modeling with biodiesel fuel in AVL library and experiment were close to each other. In the experimental study, it was aimed to minimize the margin of error by making an average calculation of 200 cycles for all test fuels. When the B10 and B20 fuels were compared to diesel fuel, the maximum pressure values in-cylinder had slightly increased. There were different reasons for this increase. The first of these was that the biodiesel fuels have a higher density than diesel fuel. The biodiesel fuel injected from the injector may had increased the maximum pressure by spraying more fuel per unit volume. Another reason was the oxygen found in the chemical structure of biodiesel fuel. It could be said that the amount of oxygen is higher in the combustion chamber and the fuel breaks down more easily by increasing the temperature in-cylinder. This situation could be said to cause a slight increase in maximum pressures. As a matter of fact, these results also overlap with the combustion analysis performed in the AVL Fire program.

Increases in penetration depths due to the use of biodiesel fuels and the separation of the fuel into smaller particles performed a more homogenous distribution of the fuel in the combustion chamber. This was thought to be effective in increasing the maximum pressures in biodiesel blended fuels. The fact that the experimental results obtained with different fuels and the numerical results were similar to each other, the results obtained by the addition of hydrogen to test fuels were also validate in modeling.

By adding $3 \%$ and $6 \%$ hydrogen to fuels, the incylinder pressure changes depending on the crank angle were given numerically in Figure 4. Hydrogen compared to diesel and biodiesel fuels, the maximum pressures in the cylinder increased in all mixtures where hydrogen was added due to the high flame velocity and high thermal value.

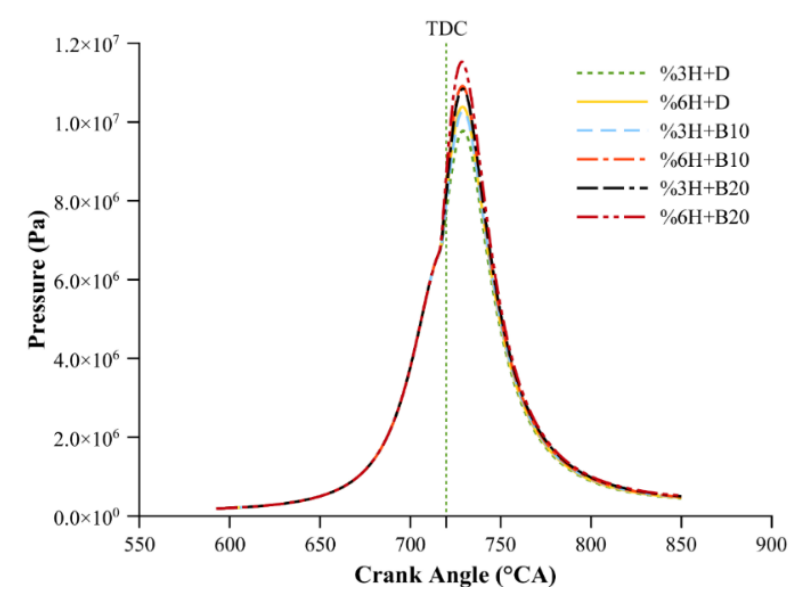

Figure 4. Pressure change in-cylinder by addition of hydrogen to fuels at different mixing ratios.

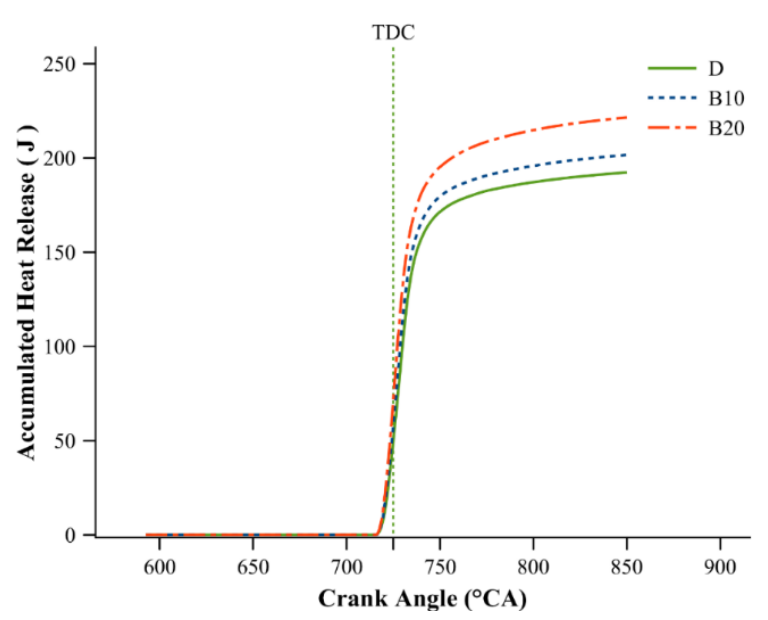

a

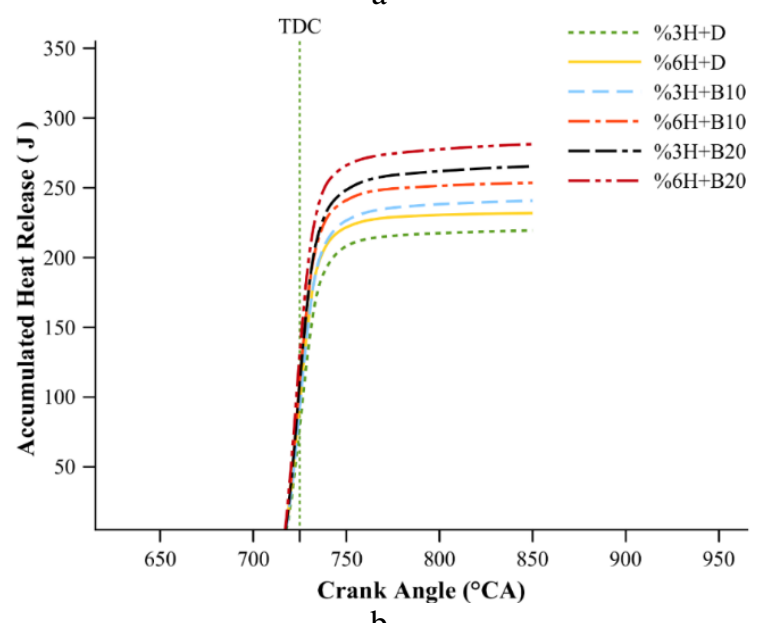

Figure 5. Change of accumulated heat release diesel and biodiesel fuel mixtures (a) and the addition of hydrogen to fuels (b).

In addition, the in-cylinder combustion behavior of hydrogen fuel and biodiesel fuels were 
examined. In particular, these two fuels had improved the combustion process, and oxygen in the structure of biodiesel fuels provides better combustion with hydrogen fuel and in Figure 5 was shown that the resulting heat release is increased. Accumulated heat release (AHR) rate provides information on combustion in engines. Accumulated heat release values increase in parallel with the increase in-cylinder pressure and temperature of biodiesel blended fuels. In particular, increased in ignition delay durations as a function of the cetane number of fuels had increased the maximum heat release, and in parallel to this, had increased at maximum incylinder temperatures. As a matter of fact, this situation was clearly seen in spray distribution and temperature graphs.

\subsection{The formation of local $\mathrm{CO}$}

Hydrogen fuel has many advantages such as ignition limits in wide A / F ratios, absence of carbon components, high octane numbers, high thermal value compared to gasoline and diesel fuels. Its use as a double fuel is quite common due to this advantages. In diesel engine used by $10 \%$ and $20 \%$ canola oil methyl ester were mixed with diesel fuel. $3 \%$ and $6 \%$ hydrogen were added to eliminate some disadvantages of this fuel mixture. The dispersion and combustion process resulting from spraying the fuels into the combustion chamber were analyzed experimentally and numerically.

In numerical analysis; especially in-cylinder $\mathrm{CO}$ formation, spray distribution and temperature formation were investigated extensively for each model. $\mathrm{CO}$ is a kind of harmful emission caused by toxic and incomplete combustion. The formation of $\mathrm{CO}$ varies greatly depending on the air / fuel ratio. The CO emission formation was obtained for all test fuels at different crank angles in-cylinder. Combustion and emissions occurring were investigated before and after the 720 crank which is accepted as TDC in the engine. The $\mathrm{CO}$ formation in the combustion chambers was investigated at four different crank angles, $715^{\circ}, 720^{\circ}, 730^{\circ}$ and $735^{\circ}$. In the below figures were given the $\mathrm{CO}$ distribution in the combustion chambers of fuel mixtures D, B10, B20, D + 3\% H, D + 6\% H, $\mathrm{B} 10+3 \% \mathrm{H}, \mathrm{B} 10+6 \% \mathrm{H}, \mathrm{B} 20+3 \% \mathrm{H}$ and $\mathrm{B} 20$ $+6 \% \mathrm{H}$ (Figure 6). When the figures were examined, the highest $\mathrm{CO}$ formation was obtained in the study using pure diesel fuel. It was thought that oxygen in the structure of canola oil methyl ester is a factor that improves combustion. As a result of the recovery of combustion, $\mathrm{CO}$ emissions had also decreased with the increase in the rate of biodiesel fuel. In particular, by adding hydrogen to diesel, B10 and B20 fuels have caused significant reductions in $\mathrm{CO}$ emissions (Figure 6). In addition, significant reductions in $\mathrm{CO}$ emissions were observed due to the lack of carbon in the structure of hydrogen. In particular, the lowest $\mathrm{CO}$ emission formation was observed in the B20 studies with hydrogen added. Another factor in the reduction of $\mathrm{CO}$ emissions was that hydrogen fuel had improved evaporation by increasing combustion temperatures in the combustion chamber. In addition, the high flame speed of hydrogen fuel compared to diesel and biodiesel fuels had led to better combustion of the fuel mixture. The homogeneous mixture of biodiesel fuels with air in the cylinder was another factor in the reduction of $\mathrm{CO}$ emissions. In all test fuels, local $\mathrm{CO}$ formation is lower at the angle of 5 degrees before the TDC (Figure 6 ). This situation could been seen more clearly in the spray distribution / temperature patterns of the fuel.

In all test fuels, in parallel with the increase in cylinder temperature and pressure, the evaporation of the fuel and the air-mixing rate were more clearly seen at the $720^{\circ}$ crank angle. The combustion effect was quite high at $730^{\circ}$ crank angle. In the process of initiation and continuation of combustion, $\mathrm{CO}$ formation is observed in a wider area by the end of the spraying at the $735^{\circ}$ crank angle.

\subsection{Spray distribution / temperature formation}

In diesel engines, the penetration depth and spray formation in the combustion chambers are very important on the fuel / air mixture ratio. At the same time, the formation of in-cylinder temperature and the distribution of fuel particles give important information about combustion. In the following figures, the spray distributiontemperature distributions in the combustion chambers were given at different crank angles of the fuel mixtures D, B10, B20, D + 3\% H, D + $6 \% \mathrm{H}, \mathrm{B} 10+3 \% \mathrm{H}, \mathrm{B} 10+6 \% \mathrm{H}, \mathrm{B} 20+3 \% \mathrm{H}$ and $\mathrm{B} 20+6 \% \mathrm{H}$ (Figure 7 ). 

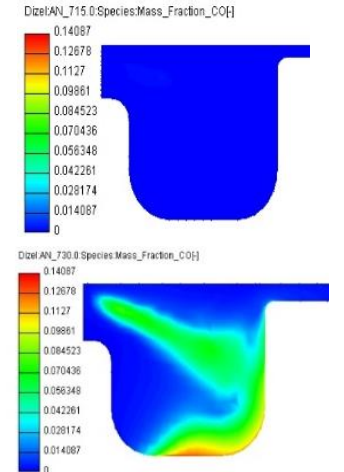

D
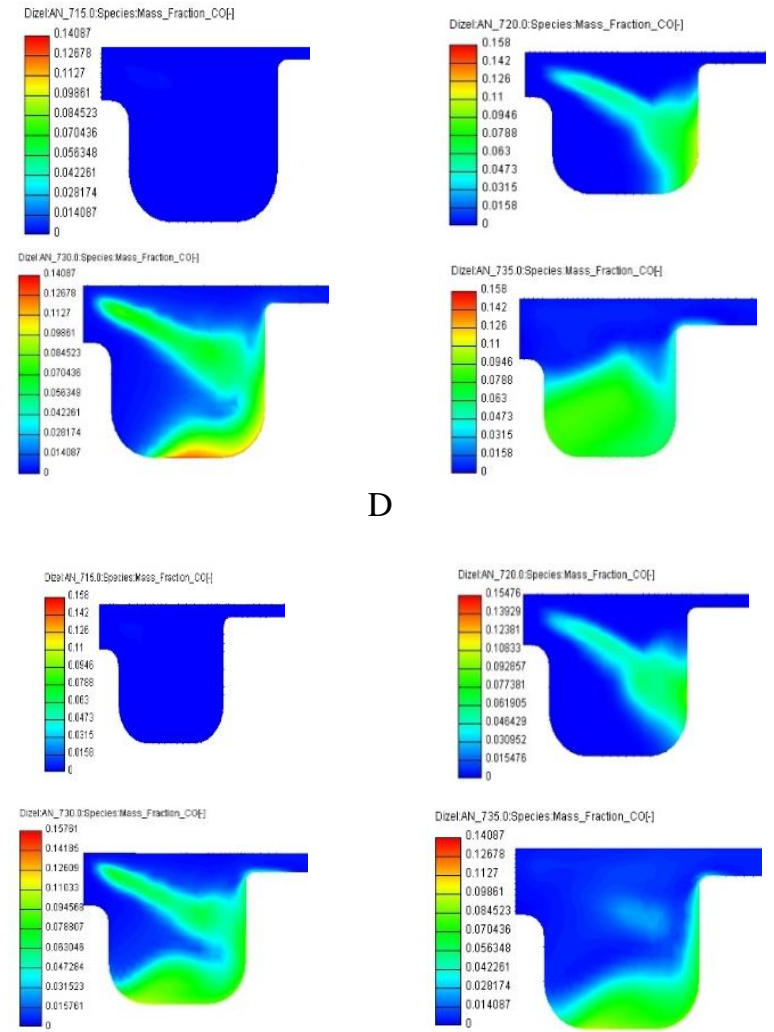

B20
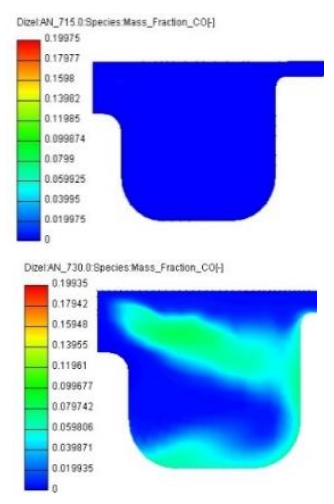

$\mathrm{D}+6 \% \mathrm{H}$
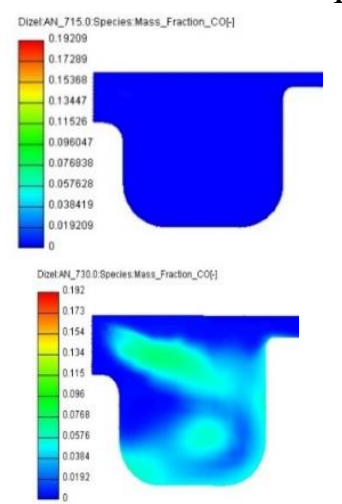

$\mathrm{B} 10+6 \% \mathrm{H}$
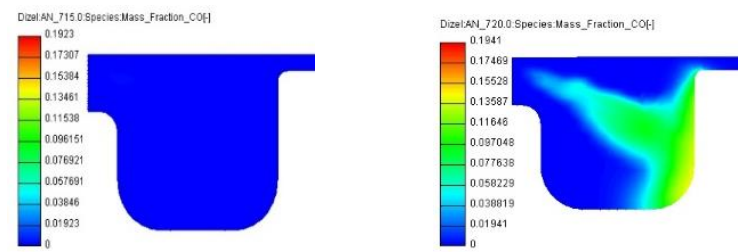
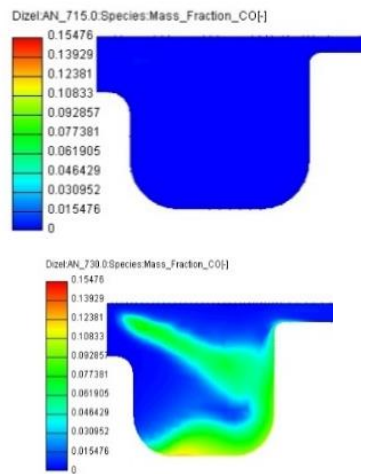

$\mathrm{B} 10$
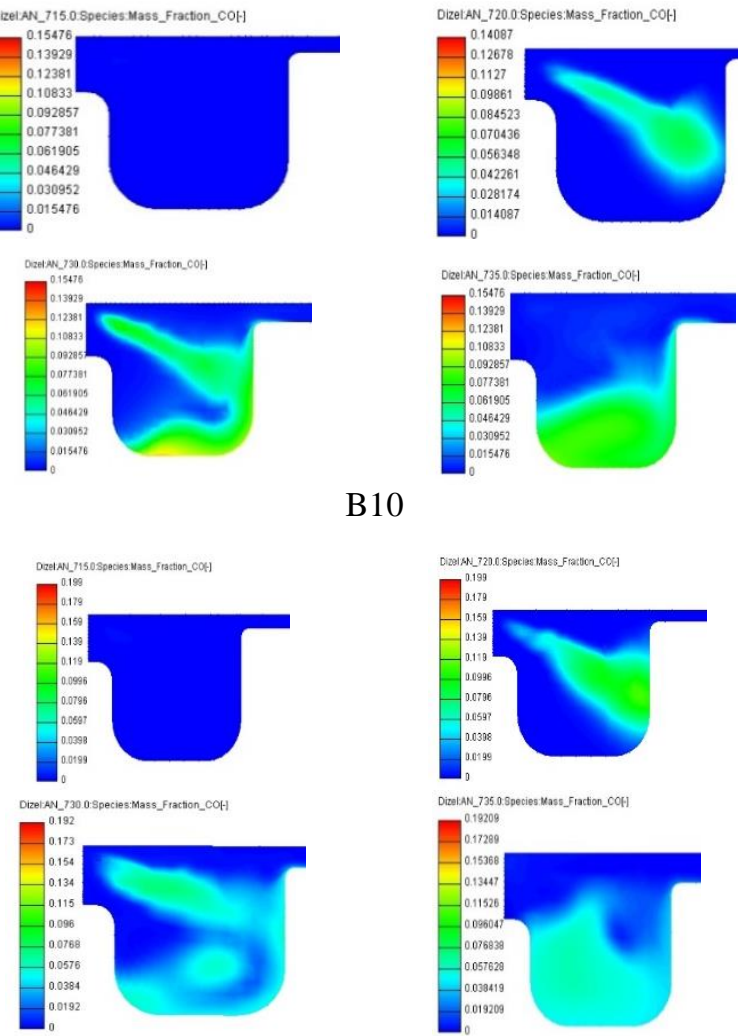

$\mathrm{D}+3 \% \mathrm{H}$
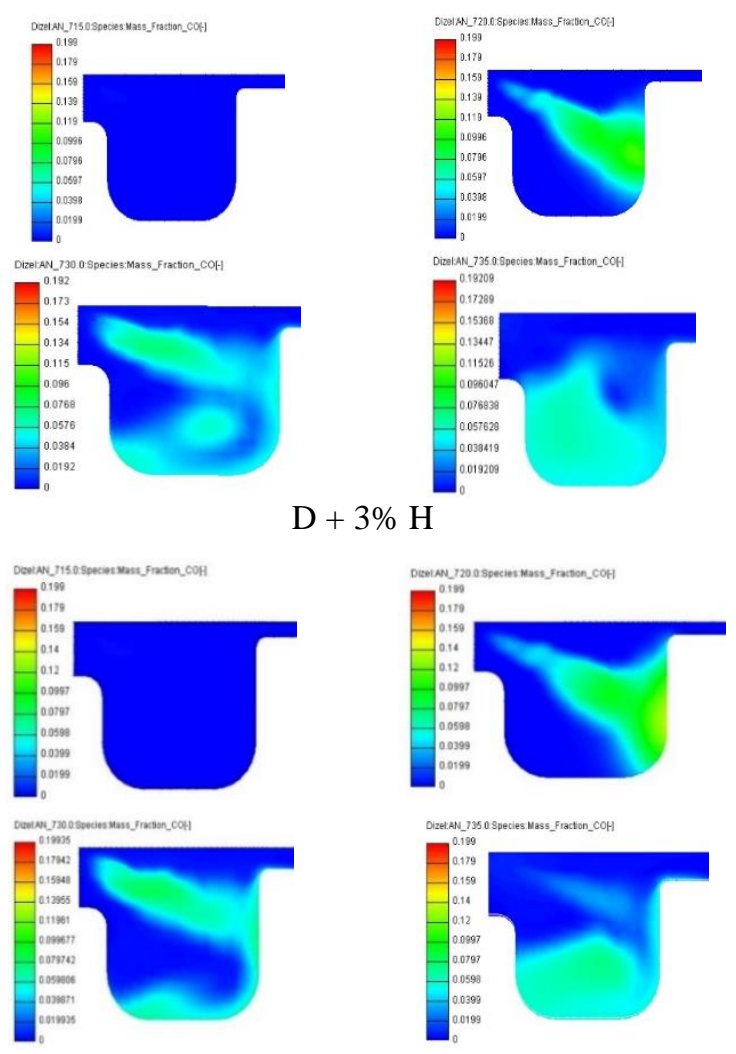

$\mathrm{B} 10+3 \% \mathrm{H}$
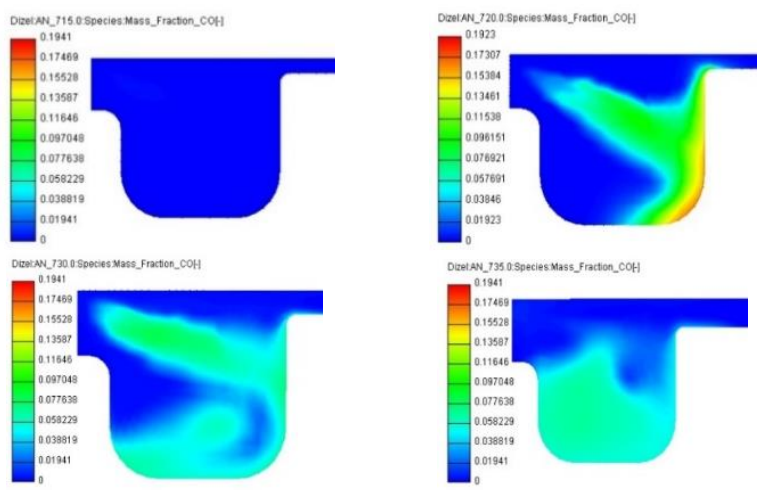

$\mathrm{B} 20+3 \% \mathrm{H}$
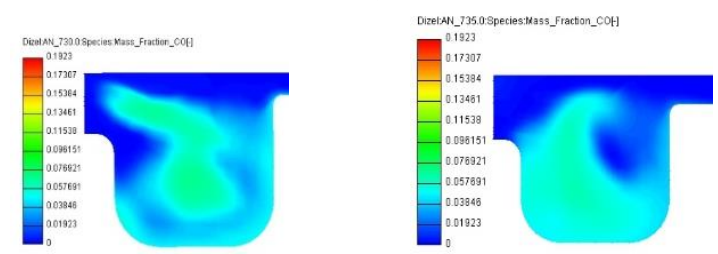

$\mathrm{B} 20+6 \% \mathrm{H}$

Figure 6. Investigation of the in-cylinder $\mathrm{CO}$ emission in different fuel mixtures. 
Especially the high viscosity and density of biodiesel fuels was a negative result in terms of combustion and emissions. However, when the engine was operating at $2000 \mathrm{rpm}$, the inclusion of oxygen in the structure of biodiesel fuel and the injection of excess fuel due to its density increased the in-cylinder combustion temperatures compared to the diesel fuel used. This effect of the temperature had improved the decomposition and penetration of the fuel into smaller particles by eliminating this negative situation caused by the fuel viscosity. In all the test studies, the dispersion of the flame in the combustion chamber was given with the end of spraying at the 731 crank angle. With the advancement of the crank angle, it had been observed that the fuels have broken down and continued to burn in the chamber pocket (Figure 7). The fuel particles that were plastered to the combustion chamber walls started to burn due to the temperature and caused the temperatures to increase in this region. At the first outlet of the injector, larger fuels were decomposed into small fuel particles together with in-cylinder temperatures and mixture formation. In particular, biodiesel blended fuels compared to diesel fuel had been observed that it had a longer carbon-hydrogen chemical chain structure, the excess oxygen and the decomposition of smaller fuel particles due to high temperatures. Also, B10 and B20 fuels had higher combustion temperatures than $\mathrm{D}$ fuel. In addition, the separation of B10 and B20 fuels into smaller particles increases the penetration of the spray . Reduction of the stress applied to the fuel surface by separating the fuel into small particles, it caused the fuel particles to continue to exist in the combustion chamber. Adding 3\% and $6 \%$ hydrogen fuel to the D, B10 and B20 fuels have highly affected the particle distribution and temperature formation (Figure 7). For example, when the piston was at the TDC, the maximum temperatures obtained in the combustion chamber for D, B10 and B20 fuels were recorded as $2498 \mathrm{~K}, 2529 \mathrm{~K}$ and 2571 $\mathrm{K}$ respectively. Both the increase in the rate of biodiesel and the increase in the rate of additional hydrogen fuel had led to an increase in these temperatures. For example, when $3 \%$ and $6 \%$ hydrogen were added to the $\mathrm{D}$ fuel, the combustion temperatures were $2612 \mathrm{~K}$ and 2671 $\mathrm{K}$, respectively. Similarly, when $3 \%$ and $6 \%$ hydrogen were added to the B10 fuel, the combustion temperatures were $2644 \mathrm{~K}$ and 2701 $\mathrm{K}$ respectively. When $3 \%$ and $6 \%$ hydrogen were added to the B20 fuel, the combustion temperatures were $2675 \mathrm{~K}$ and $2719 \mathrm{~K}$ respectively. Also, in Table 5 was showed the maximum spray sauter diameters $(\mathrm{d} 32 \mathrm{~m})$ of different fuels. These results confirm the abovementioned sentences. The addition of hydrogenbiodiesel and diesel fuel caused a decrease in the maximum spray sauter diameter (d32 m).

Table 5. The maximum spray sauter diameter $(\mathrm{d} 32 \mathrm{~m})$ of different fuels

\begin{tabular}{lc}
\hline \multicolumn{1}{c}{ Fuel } & $\begin{array}{c}\text { The maksimum Spray Sauter } \\
\text { Diameter }(\mathbf{d 3 2} \text { m) }\end{array}$ \\
\hline $\mathrm{D}$ & 0.00015135 \\
$\mathrm{~B} 10$ & 0.00015096 \\
$\mathrm{~B} 20$ & 0.00015095 \\
$\mathrm{D}+3 \% \mathrm{H}$ & 0.00015068 \\
$\mathrm{D}+6 \% \mathrm{H}$ & 0.00014952 \\
$\mathrm{~B} 10+3 \% \mathrm{H}$ & 0.00015068 \\
$\mathrm{~B} 10+6 \% \mathrm{H}$ & 0.00015026 \\
$\mathrm{~B} 20+3 \% \mathrm{H}$ & 0.00015078 \\
$\mathrm{~B} 20+6 \% \mathrm{H}$ & 0.00015022 \\
\hline
\end{tabular}

\section{Conclusions}

In this conducted study, D, B10 and B20 fuels were investigated experimentally and numerically in a direct injection diesel engine. The engine was operated at $2000 \mathrm{rpm}$ with engine speed and full load. All other engineparameters were kept constant to understand the effect of fuels. In the experimental study, it was aimed to minimize the margin of error by making an average calculation of 200 cycles for all test fuels. In this study were examined parameters such as incylinder pressure change, accumulated heat release, the formation of local $\mathrm{CO}$, spray distribution and temperature formation in different fuel mixtures and the change of temperature and the distribution of fuel particles in different fuel mixture. When the B10 and B20 fuels were compared to diesel fuel, the maximum pressure values in-cylinder had slightly increased. The reason of this could be said that the oxygen found in the chemical structure of biodiesel fuel and higher density than diesel fuel. Also, increases in penetration depths due to the use of biodiesel fuels and the separation of the fuel into smaller particles performed a more homogenous distribution of the fuel in the combustion chamber. 

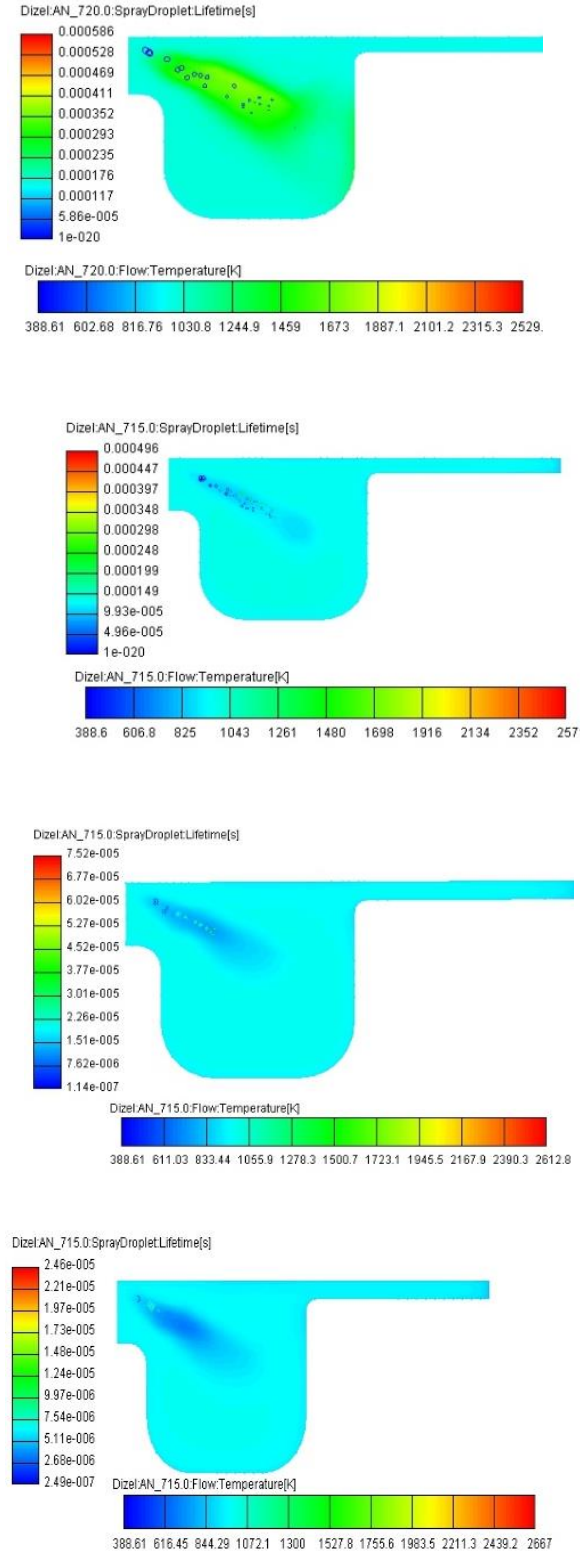
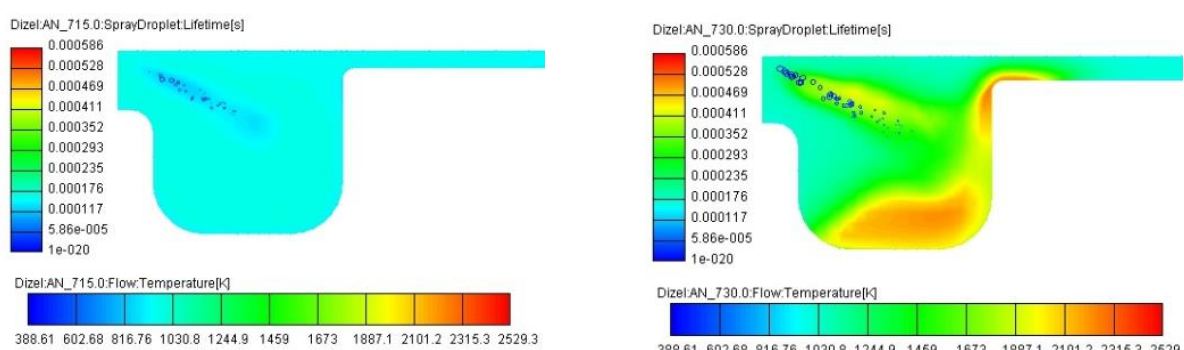

B10
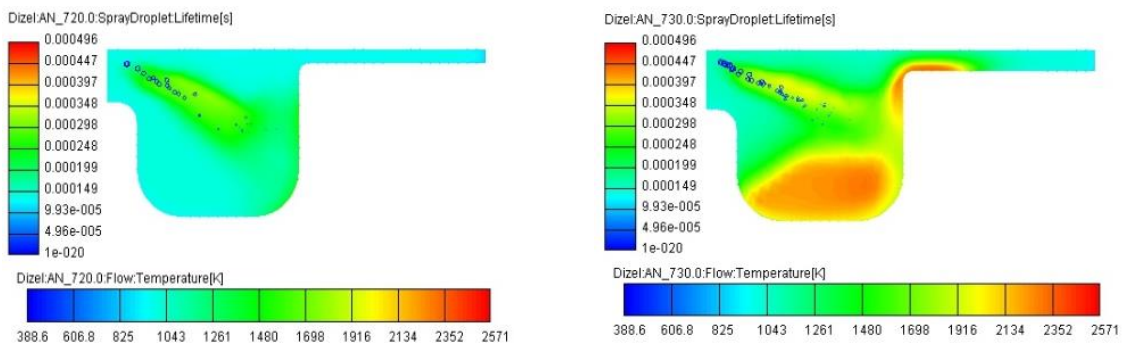

B20
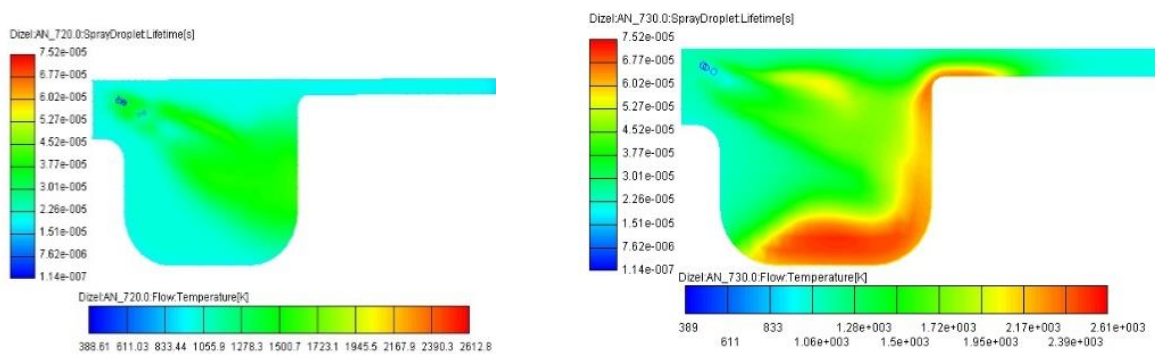

$\mathrm{D}+3 \% \mathrm{H}$
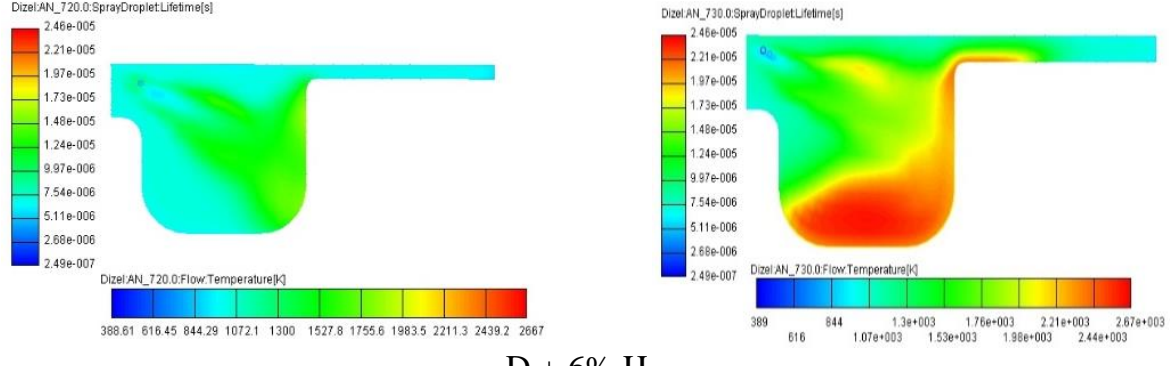
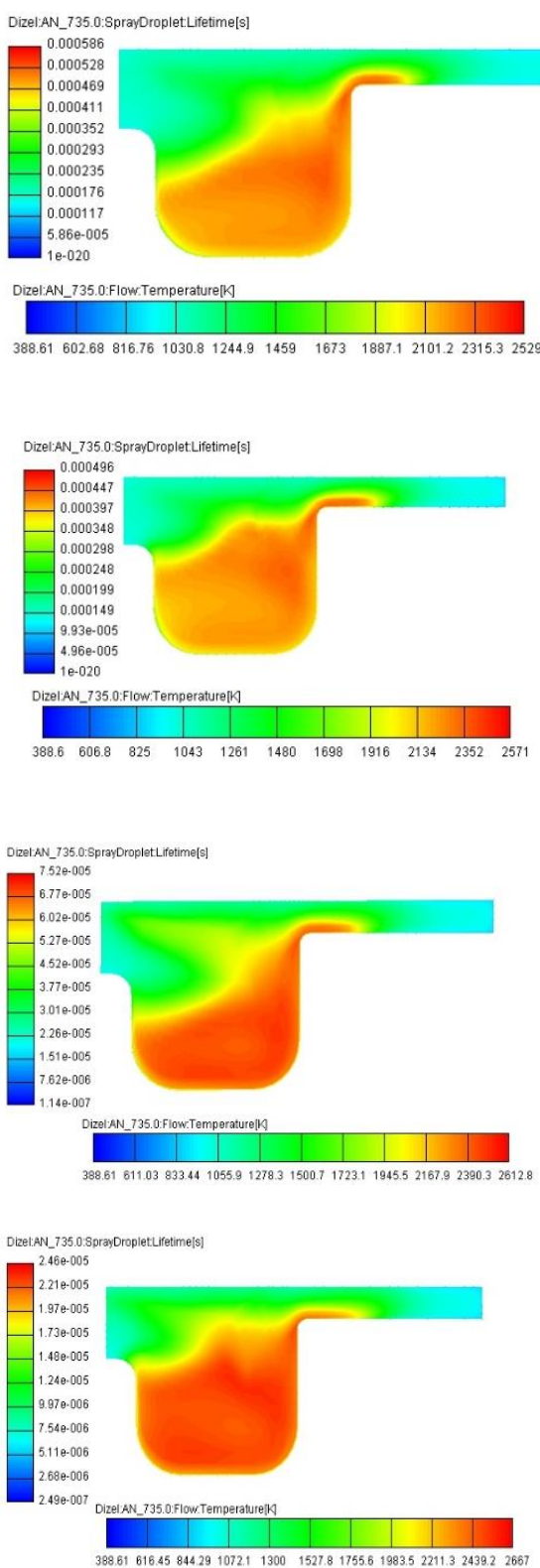

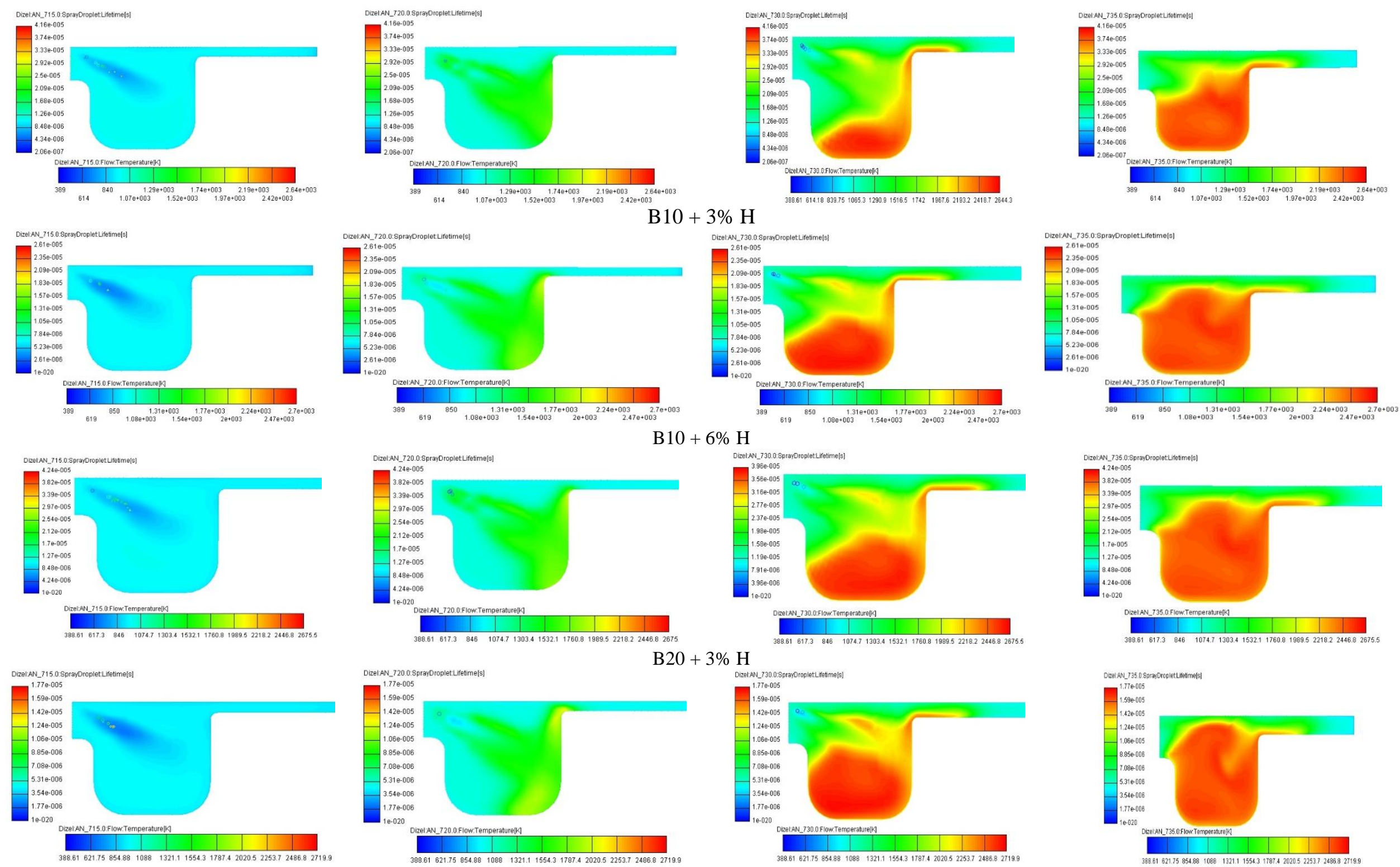

$\mathrm{B} 20+6 \% \mathrm{H}$

Figure 7. The formation of in-cylinder temperature and the distribution of spray droplet in different fuel mixture. 
When the ratio of in-cylinder pressure and accumulated heat release were examined, it was seen that the experimental and numerical results were close to each other. This situation proved the accuracy of the results obtained from the numerical study. Then, the effect of hydrogen was investigated numerically by adding $3 \%$ and $6 \%$ hydrogen to $\mathrm{D}, \mathrm{B} 10$ and B20 fuels. By adding of hydrogen fuel, the high flame speed of the fuel and the high heat value of the hydrogen fuel compared to diesel and biodiesel fuels, and it increased the in-cylinder maximum pressures in all the operations. Hydrogen and biodiesel fuels had improved the combustion process, and oxygen in the structure of biodiesel fuels provides better combustion with hydrogen fuel and this situation, accumulated heat release was increased. The maximum flame zone was obtained by using B20 $+6 \% \mathrm{H}$ mixed fuel in the combustion chamber. Increasing the rate of hydrogen in biodiesel blended fuels was provided easier disintegration of the fuel and distribution within the combustion chamber. It was concluded that the addition of hydrogen to biodiesel fuels with low cetane numbers a factor that facilitates combustion.

Investigation of the thermal and chemical effects of the addition of hydrogen to may use in both diesel and biodiesel fuels may be the next study on engine parts.

\section{Nomenclature}

$\begin{array}{ll}\mathrm{D} & \text { : Diesel } \\ \mathrm{H} & \text { : Hydrogen } \\ \mathrm{TDC} & \text { : Top Dead Center } \\ \mathrm{CA} & \text { : Crank Angle } \\ \mathrm{A} / \mathrm{F} & : \text { Air/Fuel } \\ \mathrm{CFD} & : \text { Computational Fluid Dynamic } \\ \mathrm{CO} & : \text { Carbon monoxide } \\ \mathrm{HC} & : \text { Hydrocarbon } \\ \mathrm{O}_{2} & \text { : Oxygen } \\ \mathrm{RME} & \text { : Rapeseed Methyl Ester } \\ \mathrm{AHR} & \text { : Accumulated Heat Release }\end{array}$

\section{References}

1. K R Patil, P M Khanwalkar, S S Thipse, K P Kavathekar, S D Rairikar, Development of $\mathrm{HCNG}$ blended fuel engine with control of $\mathrm{NO}_{\mathrm{x}}$ emissions, 2nd International Conference on Emerging Trends in Engineering \& Technology (ICETET-09), TII - 423 (2009), 1068-1074.

2. A A Taha, T Abdel-Salam, M Vellakal,
Hydrogen, biodiesel and ethanol for internal combustion engines: a review paper, Proceedings of the ASME 2015 Internal Combustion Engine Division Fall Technical Conference, ICEF2015, 1-11.

3. C M White, R R Steeper, A E Lutz, The hydrogen-fueled internal combustion engine: a technical review, International Journal of Hydrogen Energy, 31 (2006), 1292 - 1305.

4. N K Patil, S V Prayagi, CFD analysis of single cylinder HCNG engine: a review, International Research Journal of Engineering and Technology (IRJET), 4:5 (2017), 26322636.

5. P Dimiriou, $\mathrm{T}$ Tsujimura, A review of hydrogen as a compression ignition engine fuel, International Journal of Hydrogen Energy, 42 (2017), 24470 - 24486.

6. B A Çeper, Use of hydrogen-methane blends in internal combustion engines, Chapter 7, Hydrogen Energy - Challenges and Perspectives Book, http://dx.doi.org/10.5772/50597, 01.17.2017. 175-200.

7. Fulton J, Lynch F, Marmora R. Hydrogen for reducing emissions from alternative fuel vehicle, SAE Technical Paper, 1993; No. 931813.

8. K Nanthagopal, R Subbarao, T Elango, $\mathrm{P}$ Baskar, K Annamalai, Hydrogen enriched compressed natural gas ( $\mathrm{HCNG})-$ A futuristic fuel for internal combustion engines, Thermal Science 15:4 (2011),1145-1154.

9. H Köse, M Ciniviz, An experimental investigation of effect on diesel engine performance and exhaust emissions of addition at dual fuel mode of hydrogen, Fuel Processing Technology 114 (2013) 26-34.

10. A Mariani, B Morrone, A Unich, A review of hydrogen-natural gas blend, fuels in internal combustion engines, Fossil Fuel and the Environment, (2012), 17-36.

11. F Halter, C Chauveau, N DjebailiChaumeix, I, Gökalp, Characterization of the effects of pressure and hydrogen concentration on laminar burning velocities of methanehydrogen-air mixtures, Proceedings of the Combustion Institute 30 (2005), 201-208.

12. Z Chen, Effects of hydrogen addition on the propagation of spherical methane/air flames: A computational study, International Journal of Hydrogen Energy, 34 (2009), 6558 - 6567. 
13. G P McTaggart-Cowan, S R Munshi, S N Rogak, P G Hill, W K Bushe, Hydrogenmethane blend fuelling of a heavy-duty, directinjection engine, 2007 ASME International Mechanical Engineering Congress and Exposition, Proceedings of IMECE2007, 1-10.

14. B Morrone, A Unich, Numerical investigation on the effects of natural gas and hydrogen blends on engine combustion, International Journal of Hydrogen Energy, 34 (2009), 4626 - 4634.

15. S Tangöz, S O Akansu, N Kahraman, Effects of compression ratio on performance and emissions of a modified diesel engine fueled by HCNG, International Journal of Hydrogen Energy, 40 (2015), 15374 - 15380.

16. S Reddy, M Dutta, K V K Reddy, Effect of Compression Ratio on Performance of a Hydrogen Blended CNG-Diesel Dual Fuel Engine, Journal of Mechanical Engineering, 44:2 (2014), 87-93.

17. S O Akansu, Z Dulger, N Kahraman, T $\mathrm{N}$ Veziroğlu, Internal combustion engines fueled by natural gas-hydrogen mixtures, International Journal of Hydrogen Energy, 29 (2004), 1527 - 1539.

18. J Xu, $X$ Zhang, J Liu, L Fan, Experimental study of a single-cylinder engine fueled with natural gas-hydrogen mixtures, International Journal of Hydrogen Energy, 35 (2010), 2909 - 2914.

19. J Wang, Z Huang, Y Fang, B Liu, K Zeng, H Miao, D Jiang, Combustion behaviors of a direct-injection engine operating on various fractions of natural gas-hydrogen blends, International Journal of Hydrogen Energy, 32 (2007), 3555 - 3564.

20. H T Arat, K Aydın, E Baltacıoğlu, E Yaşar, M K Baltacıoğlu, Ç Conker, A Burgaç, A review of hydrogen-enriched compressed natural gas (HCNG)-fuel in diesel engines, A Journal of Macro Trends in Energy and Sustainability, 1:1 (2013), 115-122.

21. M S Kumar, S V Karthic, P Pradeep, Investigations on the influence of ethanol and water injection techniques on engine's behavior of a hydrogen - biofuel based dual fuel engine, International Journal of Hydrogen Energy, 43 (2018), $21090-21101$.

22. G Tüccar, E Uludamar, Emission and engine performance analysis of a diesel engine using hydrogen enriched pomegranate seed oil biodiesel, International Journal of Hydrogen Energy, 43 (2018), 18014 - 18019.

23. H Serin, Ş Y1ldızhan, Hydrogen addition to tea seed oil biodiesel: Performance and emission characteristics, International Journal of Hydrogen Energy, 43 (2018), 18020 - 18027. 24. M A Akar, E Kekilli, O Bas, S Yıldızhan, H Serin, M Ozcanli, Hydrogen enriched waste oil biodiesel usage in compression ignition engine, International Journal of Hydrogen Energy, 43 (2018), 18046 -18052 .

25. M Parthasarathy, J I J R Lalvani B Dhinesh, K Annamalai, Effect of hydrogen on ethanol-biodiesel blend on performance and emission characteristics of a direct injection diesel engine, Ecotoxicology and Environmental Safety,134 (2016), 433-439.

26. M S Kumar, A Ramesh, B Nagalingam, Use of hydrogen to enhance the performance of a vegetable oil fuelled compression ignition engine, International Journal of Hydrogen Energy, 28 (2003), 1143 - 1154.

27. R Chiriac, N Apostolescu, Emissions of a diesel engine using B20 and effects of hydrogen addition, International Journal of Hydrogen Energy, 38 (2013), 13453 - 13462.

28. M Aldhaidhawi, R Chiriac, V Badescu, $G$ Descombes, $P$ Podevin, Investigation on the mixture formation, combustion characteristics and performance of a Diesel engine fueled with Diesel, Biodiesel B20 and hydrogen addition, International Journal of Hydrogen Energy, 42 (2017), 16793 - 16807.

29. S Imran, D R Emberson, B Ihracska, D S Wen, R J Crookes, T Korakianitis, Effect of pilot fuel quantity and type on performance and emissions of natural gas and hydrogen based combustion in a compression ignition engine, International Journal of Hydrogen Energy, 39 (2014), 5163 - 5175.

30. S Imran, T Korakianitis, R Shaukat, M Farooq, S Condoor, S Jayaram, experimentally tested performance and emissions advantages of using natural-gas and hydrogen fuel mixture with diesel and rapeseed methyl ester as pilot fuels, Applied Energy, 229 (2018), 1260-1268. 31. T Korakianitis, A M Namasivayam, R J Crookes, Diesel and rapeseed methyl ester (RME) pilot fuels for hydrogen and natural gas dual-fuel combustion in compression-ignition engines, Fuel, 90 (2011), 2384-2395. 
32. S Imran, D R Emberson, A Hussain, H Ali, B Ihracska, T Korakianitis, Performance and specific emissions contours throughout the operating range of hydrogen-fueled compression ignition engine with diesel and RME pilot fuels, Alexandria Engineering Journal, 54 (2015), 303-314.

33. S Imran, D R Emberson, A Diez, D S Wen, R J Crookes, T Korakianitis, Natural gas fueled compression ignition engine performance and emissions maps with diesel and RME pilot fuels, Applied Energy, 124 (2014), 354-365.

34. S Imran, D R Emberson, D S Wen, A Diez, R J Crookes, T Korakianitis, Performance and specific emissions contours of a diesel and RME fueled compression-ignition engine throughout its operating speed and power range, Applied Energy, 111 (2013), 771-777.

35. B Alpgiray, Kanola yağının diesel motorunun performansina ve emisyon karakteristiklerine etkilerinin belirlenmesi, Ankara University, Master's thesis, Institute of science and technology, 2006.

36. S Wei, F Wang, X Leng, X Liu, K Ji, Numerical analysis on the effect of swirl ratios on swirl chamber combustion system of DI diesel engines, Energy Conversion and Management, 75 (2013), 184-190.

37. B V V S U Prasad, C S Sharma, T N C Anand, R V Ravikrishna, High swirl-inducing piston bowls in small diesel engines for emission reduction, Applied Energy, 88:7 (2011) 2355-2367.

38. F Payri, J Benajes, X Margeo, A Gil, CFD modeling of the in-cylinder flow in directinjection diesel engine, Computers \& Fluids, 33:8 (2004), 995-1021.

39. H Köten, Performans analysis of a diesel engine within a multi-dimensional framework, Journal of Thermal Engineering, 4:4 (2018), 2075-2082.

40. S M Hosseini, R Ahmadi, Performance and emissions characteristics in the combustion of co-fuel diesel-hydrogen in a heavy duty engine, Applied Energy, 205 (2017) 911-925.

41. N Boz, M Kara, O Sunal, E Alptekin, N Değirmenbaş1, Investigation of the fuel properties of biodiesel produced over an alumina-based solid catalyst, Turkish Journal of Chemistry, 33:3 (2009), 433-442. 